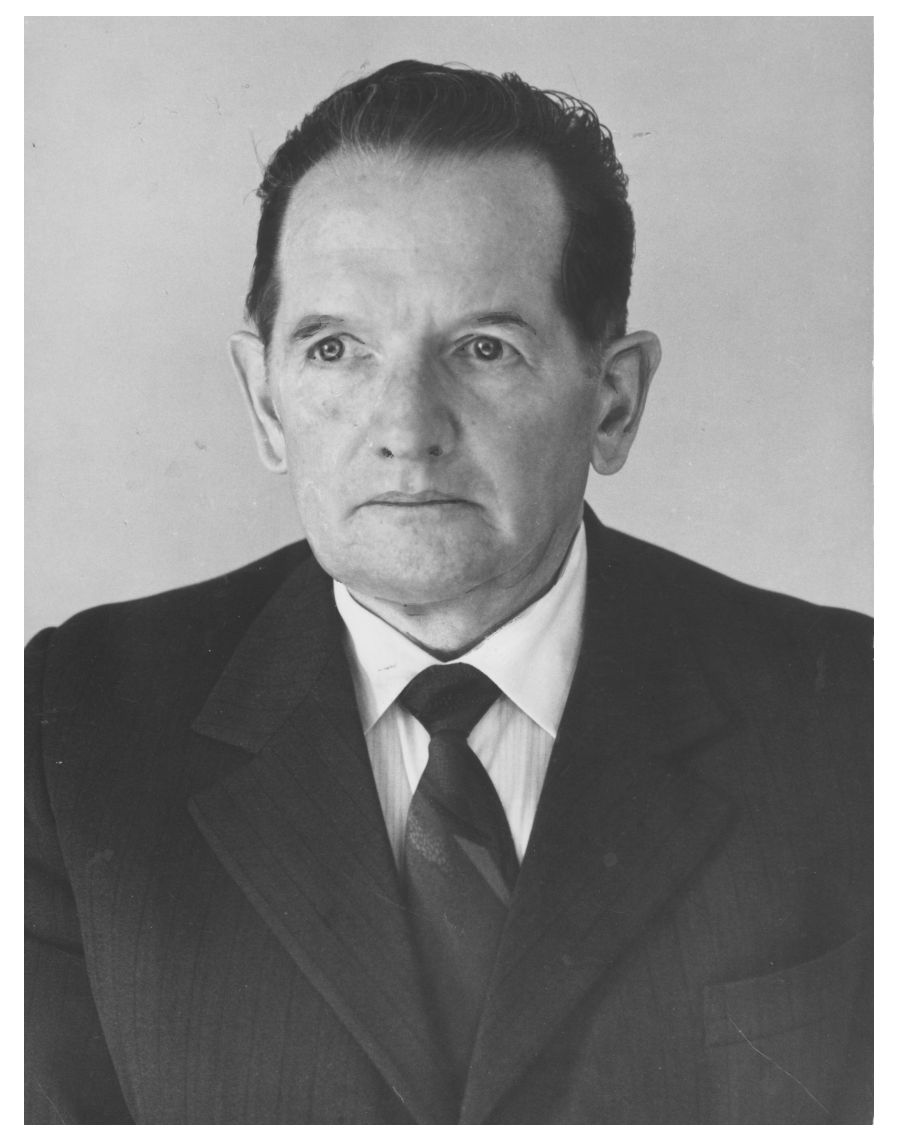

\title{
In Memory of Roman Gaida (1928-1998)
}

This volume of CMP was prepared in honour of Professor Roman Gaida on the occasion of his 70th birthday. Unfortunately, he died in Lviv on June 24, 1998. We are all saddened by his passing. It is a deep loss for the worldwide physics community.

Professor Gaida was a distinguished and prolific physicist who wrote about 150 papers. His best-known and most significant work was in the field of the relativistic theory of interacting particle systems. He is also well known for his brilliant research into the history of Ukrainian physics.

Roman Gaida was born on October 9, 1928, in the village of Pidmykhaylya in Halychyna (now Ivano-Frankivsk region). In 1946 Gaida entered the Department of Mechanics and Mathematics of Ivan Franko Lviv State University. He wrote his diploma work under the guidance of Prof. Vasyl Milianchuk (1905-1958), a theoretician of outstanding reputation in the field of quantum theory of atomic spectra. After graduating from the University in 1951, Gaida became a post-graduate student of Milianchuk.

In 1954 Gaida defended his candidate degree (Ph.D.) dissertation in the sphere of quantum field theory. He worked at Lviv University first as an assistant professor (1955-1973), then as Head of the Department of Theoretical Physics. There Gaida 
wrote his excellent textbook Atomic Physics (1965, in Ukrainian), distinguished by very clear and readable presentation of the subject. His brief lecture notes $A n$ Introduction to Theoretical Physics (1970) contain many interesting ideas about physical and mathematical foundations of classical mechanics. In the early seventies he organized a permanent seminar on the problems of relativistic mechanics, which functions till now. This seminar played a decisive role in the formation of Lviv school on relativistic physics founded by Gaida.

In 1978 Gaida left his job at the University and began to work at the Institute for Applied Problems of Mechanics and Mathematics, where he organized a research team in relativistic mechanics. The team includes Yuriy Kluchkovsky, Volodymyr Tretyak, Askold Duviryak, Yuriy Yaremko, Petro Navrotsky, Volodymyr Shpytko.

Gaida obtained the highest degree of doctorate in 1985 at the Institute of Physics (Minsk) for his research into the relativistic direct interaction theory and gravitation. In the years 1986-1991 he was Head of the Department of Physics at Lviv Zooveterinary Institute. In 1991 Gaida made what turned out to be his final career move, to the Institute for Condensed Matter Physics. He remained in this Institute until his untimely death in June 1998.

Professor R. Gaida was a full member of the Shevchenko Scientific Society, as well as a member of the Ukrainian Physical Society and the American Mathematical Society. He was Head of the Physical Committee of the Shevchenko Scientific Society and the chief editor of the Physical Collection of Shevchenko Scientific Society. Professor Gaida was also a member of editorial boards of Ukrainian Physical Journal, Condensed Matter Physics, and Svit fizyky (The World of Physics). In 1992 he was awarded Mykhaylo Hrushevskyy medal of the Shevchenko Scientific Society. His name is included in the 11th edition of Marquis' Who's Who in the World.

The early scientific interests of Gaida concerned the quantum-mechanical theory of particle collisions and its applications to the description of inter-molecular interactions. Then, he turned to theoretical investigations of interparticle collisions within the framework of quantum field theory. During 1960s he carried out research into scalar quantum electrodynamics and studied the interactions between scalar particles and electrons.

At that time Gaida intensively looked for his own way in the description of an interacting particle system at relativistic energies. The first step in this direction was the development of the notion of the approximate Lorentz invariance and its application to the construction of quasirelativistic (classical and quantum) mechanics of particle systems. In striving for the expansion of his approach beyond the first post-Newtonian approximation, Gaida came to the formulation of the three-dimensional Poincaré-invariant Lagrangian formalism in the relativistic direct interaction theory.

His investigations carried out, partly in collaboration with Yu. Kluchkovsky and V. Tretyak, clearly demonstrate the power and generality of this formalism which provides the consideration of relativistic interacting particle systems in the frame of 
a united logical scheme. The relativistic Lagrangian formalism gives a single-time three-dimensional description of particle systems based on the Poincaré-invariance conditions which are formulated in terms of Lie-Bäcklund transformations. The fundamental feature of this formalism is the dependence of the Lagrangian function on a countable infinite set of variables: space coordinates of particles and all their time-derivatives up to an infinite order.

It was shown that many-time Fokker-type action integrals can be transformed into single-time actions with nonlocal Lagrangians depending on the three-dimensional coordinates of the particles and on the derivatives of the coordinates with respect to the common evolution parameter. Such Lagrangians give a useful tool for the analysis of various approximations, as well as for the transition to the predictive relativistic mechanics and the Hamiltonian formalism. It was demonstrated that the nonlocal Lagrangians corresponding to manifestly Poincaré-invariant action integrals satisfy the Poincaré-invariance conditions within the framework of a three-dimensional Lagrangian description of interacting particle systems. The conservation laws which follow from such an invariance were investigated via the Nöther theorem. Moreover, the nonlocal single-time Lagrangians which are found on the basis of the Fokker-type action integrals represent a close form for a wide class of solutions of the equations expressing the requirement of invariance of the Lagrangian description of a particle system under the Poincaré group. The singletime Lagrangian description of particle systems was extended to an arbitrary form of relativistic dynamics defined geometrically by means of space-like foliations of the Minkowski space.

The sphere of Gaida's activity also included the problems of history and methodology of physics. In the last years he deeply studied the life and scientific activity of Ivan Puluj (1845-1918), an outstanding Ukrainian physicist, electroengineer, translator of the Bible, publicist, and an active public personality. Gaida's research into this field results in dozens publications and is summarized in the monograph Ivan Puluj prepared by him in collaboration with Roman Plyatsko and submitted for publication in 1997 to the Publishing House of the Shevchenko Scientific Society in Lviv.

The most important of Gaida's published works are listed below in the chronological order ${ }^{1}$.

1. Гайда Р. П. До теорії обміну енергією між поступальним і коливним рухом молекул // Наукові записки Львівського ун-ту. Т. 33: Фізичний збірник, 1954, вип. $1 / 6$, с. $54-58$.

2. Гайда Р. П. Про радіаційне розсіяння пі-мезонів на нуклонах // Доповіді і повідомлення ЛДУ ім. І. Франка, 1955, вип. 5, ч. 2, с. 84-85.

3. Гайда Р. П. Випромінювання фотонів при зіткненні скалярних частинок // Доповіді і повідомлення ЛДУ ім. І. Франка, 1957, вип. 7, ч. 3, с. 232-234.

\footnotetext{
${ }^{1}$ More extensive bibliography is published by the Institute for Condensed Matter Physics: Poман Гайда (1928-1998). Біобібліографічний покажчик. - Львів, 1998.
} 
4. Гайда Р. П. До питання про хвильову функцію частинки спіну нуль // Доповіді і повідомлення ЛДУ ім. І. Франка, 1957, вип. 7, ч. 3, с. 234-237.

5. Гайда Р. П. Радіаційні втрати енергії пі-мезонів при зіткненнях з нуклонами // Фізичний збірник Львівського ун-ту, 1959, вип. 2(7), с. 52-56.

6. Гайда Р. П., Дзюб І. П. Ренормалізація скалярної електродинаміки // Фізичний збірник Львівського ун-ту, 1959, вип. 2(7), с. 71-79.

7. Гайда Р. П. Випромінювання фотонів при зіткненнях скалярних частинок 3 електронами // Вісник Львівського ун-ту. Сер. фіз., 1962, вип. 1(8), с. 83-87.

8. Гайда Р. П. Атомна фізика. Підручник. Львів: Вид-во Львівського ун-ту, 1965. $-356 \mathrm{c}$.

9. Гайда Р. П. Видатний український фізик Іван Пулюй // Вісник Львівського ун-ту. Сер. фіз., 1969, вип. 5(13), с. 82-88.

10. Гайда Р. П. Функції експерименту у становленні фізичних теорій // Філософська думка, 1970, № 3, с. 68-77.

11. Гайда Р. П. Вступ до теоретичної фізики. Учбовий посібник. Львів: Вид-во Львівського ун-ту, 1970. - 72 с.

12. Гайда Р. П. Про інваріантність рівнянь руху класичної механіки відносно масштабних перетворень // Вісник Львівського ун-ту. Сер. фіз., 1972, вип. 7(15), c. $3-8$.

13. Гайда Р. П., Ключковський Ю. Б. До питання про побудову релятивістської механіки системи взаємодіючих частинок // Вісник Львівського ун-ту. Сер. фіз., 1972, вип. 7(15), с. 9-13.

14. Гайда Р. П. Лоренц-інваріантність і нерелятивістські гамільтоніани // Вісник Львівського ун-ту. Сер. фіз., 1973, вип. 8, с. 3-6.

15. Гайда Р. П. Про зв'язок між одночасностями у двох лоренцових системах відліку // Вісник Львівського ун-ту. Сер. фіз., 1973, вип. 8, с. 6-10.

16. Гайда Р. П., Гайдак В. П. Магнитные взаимодействия в классической механике системы заряженных частиц с собственными магнитными моментами // Известия вузов. Физика, 1973, № 11, с. 73-76. — In English: Magnetic interactions in a classical system of charged particles with intrinsic magnetic moments // Sov. Phys. J., 1973, vol. 16 (11), p. 1539-1541.

17. Гайда Р. П. Наближена лоренц-інваріантність і квазірелятивістські гамільтоніани. І. Класична механіка // Укр. фіз. журн., 1974, т. 19, № 9, с. 1517-1524.

18. Гайда Р. П. Наближена лоренц-інваріантність і квазірелятивістські гамільтоніани. II. Квантова механіка безспіновых частиок // Укр. фіз. журн., 1974, т. 19 , № 9 , с. $1525-1531$.

19. Гайда Р. П. Трехмерная лагранжева формулировка релятивистской проблемы двух тел в классической механике // Acta Phys. Pol. B, 1974, vol. 5, No 5, p. 613-629.

20. Гайда Р. П. Про нерелятивістську границю представлень групи Лоренца у квантовій механіці // Вісник Львівського ун-ту. Сер. фіз., 1974, вип. 9., с. 3-7.

21. Гайда Р. П. Трансформаційні властивості хвильової функції відносно наближених перетворень Лоренца // Вісник Львівського ун-ту. Сер. фіз., 1974, вип. 9 , с. $8-12$.

22. Гайда Р. П. Про умову інваріантності світової лінії у релятивістській механіці системи частинок // Вісник Львівського ун-ту. Сер. фіз., 1975, вип. 10, с. 3-4.

23. Гайда Р. П., Калиняк Б. М. Релятивістські поправки до амплітуди розсіяння 
частинки на силовому центрі // Вісник Львівського ун-ту. Cер. фіз., 1975, вип. 10 , с. $5-8$.

24. Гайда Р. П. О приближенной лоренщ-инвариантности уравнений ГамильтонаЯкоби // Известия вузов. Физика, 1975, № 12, с. 23-28. — In English: The approximate Lorentz invariance of the Hamilton-Jacobi equation // Sov. Phys. J., 1975, vol. 18, No 12, p. 1658-1662.

25. Гайда Р. П., Ключковський Ю. Б. Про релятивістську взаємодію частинки 3 зовнішнім полем // Вісник Львівського ун-ту. Сер. фіз., 1976, вип. 11, с. 6-10.

26. Гайда Р. П., Ключковський Ю. Б. До питання про зв'язок між енергією взаємодії і масою // Вісник Львівського ун-ту. Сер. фіз., 1976, вип. 11, с. 11-14.

27. Гайда Р. П., Калиняк Б. М. Методические материалы и упражнения по теоретической механике. Львов: Львовский университет, 1976. - 32 с.

28. Гайда Р. П., Ключковський Ю. Б. Трансформаційні властивості інтегралів руху класичної квазірелятивістської системи двох частинок // Укр. фіз. журн., 1977, т. 22, № 4, с. 609-616.

29. Ключковський Ю. Б., Гайда Р. П. Лагранжове формулювання релятивістської проблеми $N$ тіл у класичній теорії миттєвої далекодії // Укр. фіз. журн., 1977, т. 22 , № 4, с. $617-625$.

30. Гайда Р. П., Ключковский Ю. Б., Третяк В. И. Лагранжева классическая релятивистская механика системы прямо взаимодействующих частищ. I // Teоp. мат. физ., 1980, т. 44, № 2, с. 194-208. - In English: Lagrangian classical relativistic mechanics of a system of directly interacting particles. I // Theor. Math. Phys., 1980, vol. 44, No 2, p. 687-697.

31. Гайда Р. П., Ключковский Ю. Б., Третяк В. И. Лагранжева классическая релятивистская механика системы прямо взаимодействующих частиц. II // Teop. мат. физ., 1980, т. 45, № 2, с. 180-198. - In English: Lagrangian classical relativistic mechanics of a system of directly interacting particles. II // Theor. Math. Phys., 1980, vol. 45, No 2, p. 963-975.

32. Гайда Р. П., Крохмальский Т. Е. Приближенно релятивисткие переменные центра масс для системы двух взаимодействующих частиц // Известия вузов. Физика, 1980, № 10, с. 49-53. - In English: Approximate relativistic variables of the center of mass for a system of two interacting particles // Sov. Phys. J., 1980, vol. 23, No 10 , p. $877-881$.

33. Gaida R. P., Tretyak V. I. Single-time form of the Fokker-type relativistic dynamics. I // Acta Phys. Pol. B, 1980, vol. 11, No 7, p. 502-522.

34. Tretyak V. I., Gaida R. P. Symmetries and conservation laws in the single-time Lagrangian form of the Fokker-type relativistic dynamics. II // Acta Phys. Pol. B, 1980, vol. 11 , No 7, p. 523-536.

35. Гайда Р. П. Про неточкові перетворення в аналітичній механіці // Доповіді АН УРСР. Сер. А, 1982, № 1, с. 32-35.

36. Гайда Р. П. Квазирелятивистские системы взаимодействующих частиц // Физ. злементарных частиц и атомного ядра, 1982, т. 13, вып. 2, с. 427-493. — In English: Quasirelativistic systems of interacting particles // Sov. J. Part. Nucl., 1982, vol. 13, p. 179 .

37. Гайда Р. П., Ключковський Ю. Б., Третяк В. І. Форми релятивістської динаміки у лагранжевому описі системи частинок // Доповіді АН УРСР. Cep. A, 1982, № 5, c. 6-9. 
38. Gaida R. P. Three-dimensional Lagrangian formulation of the classical relativistic direct particle interaction theory // Проблемы физики высоких знергий и квантовой теории поля: V Междунар. семинар, Протвино, 1982. Т. 1, с. 304-315.

39. Гайда Р. П. О релятивистских поправках к классической теории дипольного излучения // Укр. физ. журн., 1982, т. 27, № 12, с. 1810-1812.

40. Гайда Р. П., Ключковский Ю. Б., Третяк В. И. Формы релятивистской динамики в классическом лагранжевом описании системы частиц // Теор. мат. физ., 1983, т. 35, № 1, с. 88-105. - In English: Forms of relativistic dynamics in the classical Lagrangian description of a system of particles // Theor. Math. Phys., 1983, vol. 55, No 1, p. 372-384.

41. Гайда Р. П., Ключковский Ю. Б., Третяк В. И. О сложении взаимодействий в квазирелятивистской механике системы частиц // Труды VI Международного семинара по проблемам физики высоких знергий и квантовой теории поля. Протвино, июль 1983. Т. І, с. 164-178.

42. Гайда Р. П., Дувиряк А. А., Ключковский Ю. Б. Мгновенная форма релятивистских уравнений движения в одной модели формализма сингулярных лагранжианов // Труды VI Международного семинара по проблемам физики высоких знергий и квантовой теории поля. Протвино, июль 1983. Т. I, c. $179-187$.

43. Gaida R. P., Kluchkovsky Yu. B., Tretyak V. I. Relativistic Lagrangian mechanics and other approaches in the direct interaction theory // Proceedings of the VII Seminar on Problems of High Energy Physics and Quantum Field Theory. Protvino, July 1984. Vol. 1, p. 99-122.

44. Гайда Р. П. О разделении внутреннего движения и движения центра масс в квазирелятивистской задаче $N$ тел // Ядерная физика, 1984, т. 39, вып. 2 , c. $478-485$.

45. Гайда Р. П.,Ключковский Ю. Б., Третяк В. И. Прямые взаимодействия частиц во втором квазирелятивистском приближении // Физика многочастичных систем, 1985, вып. 7, с. 20-30.

46. Gaida R. P., Kluchkovsky Yu. B., Tretyak V. I. Three-dimensional Lagrangian approach to the classical relativistic dynamics of directly interacting particles // Constraint's Theory and Relativistic Dynamics / G. Longhi and L. Lusanna, eds. Singapore: World Scientific Publ., 1987, p. 210-241.

47. Влох О. Г., Гайда Р. П., Пляцко Р. М. Рентген чи Пулюй? Про одну білу пляму в історії науки // Наука і суспільство, 1989, № 4, с. 18-25.

48. Гайда Р. П., Ключковский Ю. Б., Третяк В. И. Релятивистская теория прямых взаимодействий и гравитационная задача двух тел во втором постньютоновском приближении // Известия вузов. Физика, 1990, № 1, с. 48-52. In English: Relativistic theory of direct interactions and gravitational two-body problem in the second post-Newtonian approximation // Sov. Phys. J., 1990, vol. 33, No 1, p. $40-44$.

49. Гайда Р. П., Третяк В. И. Лагранжиан двух заряженных гравитирующих тел во втором постньютоновском приближении // Известия вузов. Физика, 1990, № 7, c. 31-36. In English: Lagrangian of two charged gravitating bodies in the second post-Newton approximation // Sov. Phys. J., 1990, vol. 33, No 7, p. 575-579.

50. Гайда Р. П., Ключковський Ю. Б., Третяк В. І. Теоретико-груповий підхід до побудови релятивістської лагранжевої механіки системи частинок // Укр. 
мат. журн., 1991, vol. 43, № 11, c. 1516-1520. — In English: Group-theoretic approach to the construction of relativistic Lagrangian mechanics of a system of particles // Ukrainian Math. J., 1991, vol. 43, No 11, p. 1408-1413.

51. Гайда Р. П., Третяк В. І., Яремко Ю. Г. Змінні центра мас у релятивістській лагранжевій механіці системи частинок // Укр. фіз. журн., 1991, т. 36, № 12 , c. $1807-1818$.

52. Влох О. Г., Гайда Р. П., Пляцко Р. М. Іван Пулюй та становлення рентгенології // Нариси з історії природознавства і техніки, 1994, № 41, с. 63-75.

53. Гайда Р. П., Третяк В. И., Яремко Ю. Г. Переменные центра масс в релятивистской лагранжевой динамике системы частиц // Теор. мат. физ., 1994, т. 101, № 3, c. 402-416. - In English: Center-of-mass variables in the relativistic Lagrangian dynamics of a system of particles // Theor. Math. Phys., 1994, vol. 101, No 3., p. 1433-1453.

54. Gaida R. P., Tretyak V. I., Yaremko Y. G. Lagrangian and Hamiltonian center-of-mass variables in the relativistic two-body problem // Proc. Workshops on Soft Physics "Hadrons-94". Uzhgorod (Ukraine), September 7-11, 1994. - Kiev, 1994, p. 343352.

55. Gaida R. P. Non-point transformations in classical mechanics. - Львів, 1994 24 с. - (Препринт / НАН України. Ін-т фізики конденсованих систем; ICMP-94-5E).

56. Гайда Р. Іван Пулюй (1845-1918). Фізичні дослідження // Укр. фіз. журн., 1995 , т. 40, № 1-2, с. 5-12. - Передрук у виданні: І. Пулюй. Збірник праць. К.: Рада, 1996, с. 24-36.

57. Гайда Р. Сдність науки, техніки та освіти. До 150-річчя з дня народження Івана Пулюя // Укр. освітній журн., 1995, т. 1, с. 39-54.

58. Gaida R. Er lebte und arbeitete für die Wissenschaft, der Fortschritt und die Ukraine // UBSV Vereinsjournal, 1995, № 29, S. 112-115. - Укр. мовою: Він жив і працював для науки, прогресу й України // Вісті СУФА, 1995, No 29, с. 118-121.

59. Gaida R. P., Tretyak V. I. Symmetries of the Fokker-type relativistic mechanics in various forms of dynamics // J. Nonlin. Math. Phys., 1996, vol. 3, No 3, p. 357-371.

60. Mayba I., Gaida R., Kyle R. A., Shampo M. A. Ukrainian physicist contributes to the discovery of X-rays // Mayo Clinic Proceedings, 1997, No 72, p. 658-660.

61. Гайда Р. Фізика і філософія: чи потрібні вони одна одній? // Журн. фіз. досліджень, 1997, т. 1, ч. 4, с. 477-489.

62. Гайда Р. Іван Пулюй та становлення науки про Х-промені. - Львів, 1997, 62 с. (Препринт / НАН України. Ін-т фізики конденсованих систем; ICMP-97-17U).

63. Гайда Р., Пляцко Р. Іван Пулюй. Життеписно-бібліографічний нарис. (Визначні діячі НТШ, No 7). — Львів: В-во НТШ, 1998. — 284 с. 
